\title{
TRANSPORT, URBAN DEVELOPMENT AND THE PERIPHERAL POOR IN COLOMBIA - PLACING SPLINTERING URBANISM IN THE CONTEXT OF TRANSPORT NETWORKS
}

Daniel Oviedo, MSc, Development Planning Unit, University College London, London, United Kingdom. d.oviedo.11@ucl.ac.uk

Julio D Dávila, PhD, Development Planning Unit, University College London, London, United Kingdom. j.davila@ucl.ac.uk

\begin{abstract}
In rapidly growing cities the evolution of utility and communication infrastructures has enabled the creation of 'premium networked spaces' exclusively for wealthier groups thus deepening already large social inequalities. By the same token, in a context of spatially concentrated income-earning opportunities and other urban functions, as well as limited purchasing power, accessibility to adequate means of connectivity with the rest of the urban fabric can be a determining factor in overcoming conditions of poverty for residents in physically marginal areas.

Using the case study of Soacha, a municipality adjacent to Bogotá, Colombia's capital city, we explore the evolution of vulnerable populations in peripheral informal settlements in parallel with the development of transport networks in the decade 2000-2010. Drawing on the splintering urbanism thesis we examine the apparent mismatch between the evolution of informal settlements and transport networks with the aim of identifying the effects of an uneven provision of material infrastructures and services for mobility on marginalization. We observe central elements in the structure of the networks of connectivity between Bogotá and Soacha, identifying the main gaps that lead to a fragmented set of connections. We develop a set of criteria for planners and policy makers in search of a better informed analysis of transport supply and policy development praxis for poor peripheral populations in similar regions and contexts.
\end{abstract}




\section{Introduction}

In rapidly growing cities the evolution of utility and communication infrastructures has enabled the creation of 'premium networked spaces' exclusively for wealthier groups thus deepening already large social inequalities. Privatisation and differentiated provision of infrastructure and connectivity services have allowed both the voluntary segregation of wealthy groups in well-connected developments and the total or partial disconnection of less powerful groups that find themselves forced to cope with insufficient mechanisms for interacting with the city and its opportunities.

Spatially and socially peripheral populations are often unable to adapt to rapid technological changes and to make full use of utility and transport networks. In a context of spatially concentrated income-earning opportunities and other urban functions, as well as limited purchasing power, accessibility to adequate means of connectivity with the rest of the urban fabric can be a determining factor in overcoming conditions of poverty for residents in physically marginal areas. As urban areas grow and develop and capital seeks more advantageous conditions for its reproduction, there arise processes of structuring and restructuring of networks of opportunities. In this context, wealthier groups are able to segregate themselves in premium nodes of well-connected networks, comfortably and conveniently accessing information, interacting socially and maintaining or improving their levels of welfare. More remote nodes of powerless people are simultaneously excluded as a result of the discontinuity of links and services that restrict their capacity to interact. Given that transport networks play a central role in enabling physical access to the city by the poor and thus help reduce social exclusion, a framework is needed to critically examine how transport networks bypass some groups in society. The splintering urbanism thesis (Graham \& Marvin, 2001) has helped explain growing urban gaps in access to public services and communication infrastructures, particularly in the industrialized world. We argue that several elements of their interpretation of infrastructure provision can be extended to the analysis of transport networks and services in developing countries.

This research is one of a set of initiatives within the Development Planning Unit, UCL, aimed at examining the links between mobility and poverty reduction in cities of the Global South. It builds on a two-year research project on the urban and social impact of aerial cable-cars in Medellín, Colombia's second largest city (Dávila, 2012). This paper continues this critical exploration of the links between transport and infrastructure planning on the one hand, and social inequalities and poverty in a context of rapid urbanisation, on the other. The analysis on which this article is based stems from the Medellin research project (which also examined Soacha as a second case study) and builds on the initial stages of a doctoral research focusing on the relationship between transport accessibility, social inclusion and poverty reduction in peripheral urban settlements.

The urban area selected to examine the applicability of these claims is located in the central city-region of Colombia, one of the most populous in Latin America, with around eight million inhabitants. Using the case study of Soacha, a municipality adjacent to Bogotá, Colombia's capital city, we explore the evolution of vulnerable populations in peripheral informal settlements in parallel with the development of transport networks in the decade 2000-2010. Residents in peripheral informal settlements comprise both recent low-income in-migrants and more established migrants or locals attracted by the comparatively low prices of land for housing (DPU, 2006). Land and rental prices tend to be higher in more central premium locations, but also in nearby locations in the better serviced neighbourhoods within Bogotá's administrative jurisdiction.

The limited supply of affordable land and housing for low-income groups in neighbourhoods 
that meet the requirements set by the planning system has led to the exponential rise of informally produced neighbourhoods in the periphery of Soacha (which is itself peripheral to Bogotá). This set of developments, compounded by acute social tensions within the settlements and limited income-earning opportunities in Soacha itself, presents a severe challenge to the poorly endowed and institutionally weak local government of Soacha to provide adequate utility and transport networks allowing local residents to improve currently low levels of accessibility to centres of employment in Bogotá and elsewhere (Dávila, 2012).

Peripheral settlements in Soacha could be said to be a case of geographical exclusion, one of several categories identified by Church et al. (2000) to define social exclusion. This is linked not only to a relational position in space but also to poor provision of transportation services. However, the residents of the study area are also subject to economic exclusion (Alvarez y Bocarejo, 2012), which prevents them further from affording to maintain their social or spatial contacts (Ohnmacht et al. 2009).

We examine the apparent mismatch between the evolution of informal settlements and transport networks under the aforementioned conditions with the aim of identifying the effects of an uneven provision of material infrastructures and services for mobility on marginalization (Bassols, n.d.; Quijano, 1977). From the perspective set by Graham and Marvin's thesis, we observe central elements in the structure of the networks of connectivity between Bogotá and Soacha, identifying the main gaps that lead to a fragmented set of connections. As a result, we develop a set of criteria for planners and policy makers in search of a better informed analysis of transport supply and policy development praxis for poor peripheral populations in similar regions and contexts.

\section{Splintering Urbanism as a Framework for the analysis of transport provision in peripheral urban areas.}

The notion of a networked society developed by Castells (2000) is a good starting point for introducing the applicability of the splintering urbanism thesis (Graham \& Marvin, 2001) to the analysis of transport provision in peripheral urban areas. Castells describes urban spaces as characterized by flows and networks. The first are sequences of interchanges and movements between positions within different systems of the social (Castells, 2000); the second are the material base of flows, including technological networks of communication and transportation (Manderscheid, 2009).

These conditions turn unequal material infrastructures of connectivity into a socially relevant matter as they prescribe patterns of movement of people, goods and information (Ohnmacht et al., 2009). The outcomes resulting from urban planning and the building of transportation networks can be seen as forces that either moderate or aggravate social inequalities by facilitating or restricting access to services, activities and goods (Manderscheid \& Bergman, 2008). In the specific case of transport users, travel expenditure is related to the number of connections needed to access daily activities. These connections are, in turn, reliant on networks of transport, communications and technology.

Graham and Marvin (2001) interpret networks as techno-economic constructs arising from social and historical processes, and highlight the mutual relationship between the development of networks and urban spaces (Zérah, 2007). As urban development progresses and becomes more complex, the unresponsive supply of connectivity and efficient transport infrastructure shapes networks through the concentration of activities, wealth and power within urban spaces. The splintering urbanism thesis (SU) is a response to what Graham and Marvin describe as an urgent need for developing a more robust, comprehensive approach to the understanding of "the changing relations between contemporary cities, infrastructure networks and technological mobilities" (2001:33). 
The core of the SU argument is that this dialectical relationship is currently undergoing structural changes through a:

"process of 'unbundling' and 'splintering' 'the diverse political and regulatory regimes that supported the roll-out of power, transport, communications, street and transport networks towards the rhetorical goal of standardised ubiquity" (Graham and Marvin, 2001, p. 382).

Dynamics of globalisation and liberalisation of infrastructure have led to a weakening of network monopolies. Conversely, unbundling processes arising from reforms of the infrastructure sector sought economic efficiency instead of a reduction in social and spatial inequalities. Moreover, through the constant production of high-premium spaces including, among others, gated communities, commercial complexes and high-tech economic clusters, the production of urban space is modified along with the provision of infrastructure and the increasing separation between socio-economic groups (Zérah, 2007).

Such changes allow the generation of exclusive developments termed premium networked spaces, allowing higher income groups to segregate themselves from the rest of the urban fabric while, paradoxically, remaining strongly connected to other premium spaces (Graham and Marvin, 2001). Wealthy groups in modern society see avoiding movement as a luxury, thus generating new paradigms of mobility and denying the previous nature of hypermobility as a premium, are able to shorten travel times or avoid unnecessary movements through accessing better connections and relying on comprehensive telecommunication networks. By contrast, there are social groups worldwide that lack the necessary resources and choice to be able to move and therefore are deprived from interacting with the opportunities offered by society (Bauman, 2000; Zibechi, 2008).

Mobility and the uneven nature of distribution of transport infrastructure contribute to stratify and polarize society by allowing the liberation of some groups from spatial ties while limiting others to an involuntary motionlessness (Ohnmacht et al., 2009). Differentiated mechanisms in the development of infrastructure not only allow the segregation of wealthier groups. They bypass less powerful groups thus generating inequalities in terms of their capacity to interact with the economic and social structure of the city (Graham and Marvin, 2001).

It is precisely the production of bypassing strategies in the process of infrastructure provision which makes SU a potentially useful framework for the analysis of transport provision in segregated nodes within a networked society. As the breach between connected and disconnected people intensifies, a poverty of connections is also generated, limiting "a person or group's ability to extend their influence in time and space" (Graham and Marvin, 2001, p. 288), and the identification of the causes and consequences of the practices behind this type of exclusion become central in the development of infrastructure studies. The SU approach becomes useful when interpreting the evolution of utility and communication infrastructures in rapidly growing cities both in the analysis of the production of 'premium networked spaces' exclusively for wealthier groups that deepen already large social inequalities.

Limited provision of infrastructure to certain groups in society has serious implications in terms of social exclusion, and more specifically for the focus of this research, mobility-related social exclusion. This multidimensional concept has, over the years, become a central element in policy discourse, where it is placed into, and often limited to, a context of economic poverty. Other dimensions of exclusion include spatial, political, personal and societal disadvantages that can be aggravated by poverty and in turn can help deepen poverty (Kenyon et al., 2002).

If social exclusion is understood as the combination of a set of social problems related to social fragmentation, limited access to networks of connectivity can be interpreted as a 
relevant social problem that results in a limited participation in normal processes of society leading to deprivation by certain social groups (Burchardt, 1999, Witter, 2010). In this context, an individual is socially excluded if, despite spatial proximity to main centres of activity of a society, he or she cannot participate in its normal activities (Witter, 2010).

Mobility-related social exclusion is defined as the process by which people are prevented from taking part in the opportunities that the city provides as a result of the insufficiency or inexistence of adequate means to travel (Kenyon et al., 2002). According to Grieco (2006), people that experience conditions of exclusion see their travel choice removed as a consequence of an urban environment built around the notion of high mobility. Although not all people who experience exclusion are poor nor all poor people are necessarily excluded, it is clear that circumstances leading to mobility-related social exclusion are reinforced by limited access to income and general conditions of poverty (Grieco, 2006).

Considering the social relevance and exclusionary implications of a differentiated provision of networks of transportation, a framework like Graham and Marvin's is useful in approaching the generation of limited connectivity in a context of bypassed areas in an urban space. Given its connection with relevant transport paradigms and its interpretation of infrastructure networks, the SU thesis comes in handy for identifying on-going processes in dynamic cities, especially those related to the weakness of regulation and policies of privatization and provision of infrastructure and services that may lead to an increase in inequalities and the avoidance of specific groups in the provision of infrastructure (Fernandez-Maldonado, 2008).

Some limitations of Graham and Marvin's thesis identified by some authors ought to be taken into account especially when testing its claims in the context of (1) cities in developing countries and (2) groups who are spatially segregated on the basis of their poverty as opposed to their wealth. As Coutard (2002) highlights, this thesis does not allow for specificity of each infrastructure sector. A premise of the SU thesis is that the observed changes produce a similar mismatch between globally connected spaces and bypassed areas. This leads to the perception that the authors assume that a convergence already exists in on-going processes, no matter what the sector is.

In the case of spatially and socially peripheral population groups that are often unable to adapt to technological changes and to make full use of utility networks, it is hypothesized that the limited availability of transport networks and insufficient purchasing power that prevents them from fully access faster transportation modes can have similar effects in terms of social and spatial inequalities. Graham \& Marvin (2001) have helped explain growing urban gaps in access to basic services and communication infrastructures, particularly in the industrialized world. However, the theory can be extended to the analysis of transport networks and services as these are subject to similar planning processes than utility networks and play a central role in enabling physical access to the city by the poor and thus help reduce social exclusion

The SU approach is used here as a general framework to explore these initial dynamics as it helps to understand the causes and consequences of a disconnection between the planning processes of provision of infrastructure and transport services. These analyses can be linked to the way in which housing developments evolved in the periphery of Bogotá in the decade after 2000. The specific characteristics of the area of study demand a comprehensive analysis of the dynamics of urban development and planning. This relates to conditions of poor urban governance and limited institutional capacity compounding the rapid development and consolidation of areas that merge apparently seamlessly with Bogotás urban fabric but that, at the same time, are marked by limited availability of transport networks that connect them to the main opportunity clusters in the city.

\section{The context of Bogotá-Soacha}

The Capital Region, as addressed locally, comprises the agglomeration of Bogotá DC ('Capital District') and its surrounding municipalities. While no metropolitan area for Bogotá 
has been administratively constituted, the phenomenon of constant expansion and conurbation from both sides of the city and its vicinity has led to the definition of a comprehensive figure at least in functional terms. As a result, depending on the interpretation, the region can contain up to 19 adjacent municipalities with a functional social and economic relationship with the capital city.

The developments of certain types of activities around the region and the dynamics of growth of Bogotá and some of the municipalities that are closer to it have converged in processes of conurbation and suburbanization. This has generated a complex urban structure within a context of administrative decentralization (CCB, 2005). According to census data, the strongest dynamics of conurbation and suburbanization takes place between Bogotá and the municipalities of Soacha, La Calera, Chía, Mosquera, Madrid, Funza and Facatativá, a group that has been unofficially defined as the Inner Ring. Other municipalities that have progressively strengthened its link with the city in spite of not showing yet clear spatial continuity have been assigned to a second group or Outer Ring within this practical definition of a city-region (DNP, 2005).

Bogotá is the largest and most populous city in Colombia. As the capital of the country, it houses national and regional government as well as a great share of the national production, accounting for about $25 \%$ of national GDP. According to DANE, the National Statistics Department, the population of Bogotá is about 7.5 million inhabitants, while the rest of the municipalities of the Capital Region are less than a million altogether (DANE, 2012). These characteristics make the city one of the main centres of employment in the country, supplying around 3.5 million jobs in the formal sector (CCB, 2008). This formal supply of employment is enlarged by approximately 1.8 million informal employment jobs in different sectors of the economy (CCB, 2012).

The spatial configuration of the city is centralized along a biaxial CBD. Most opportunities, not only in terms of employment, concentrate in the central part of the city (Bocarejo \& Oviedo, 2012). By comparing the location of formal productive activities in the city and the socio-economic distribution of the population using socio-economic stratification as a proxy, a high level of segregation can be observed. As shown in Figure 1, high-income social groups settle close to the CBD while the poorest live at the city's southern boundaries (Bocarejo \& Oviedo, 2012).

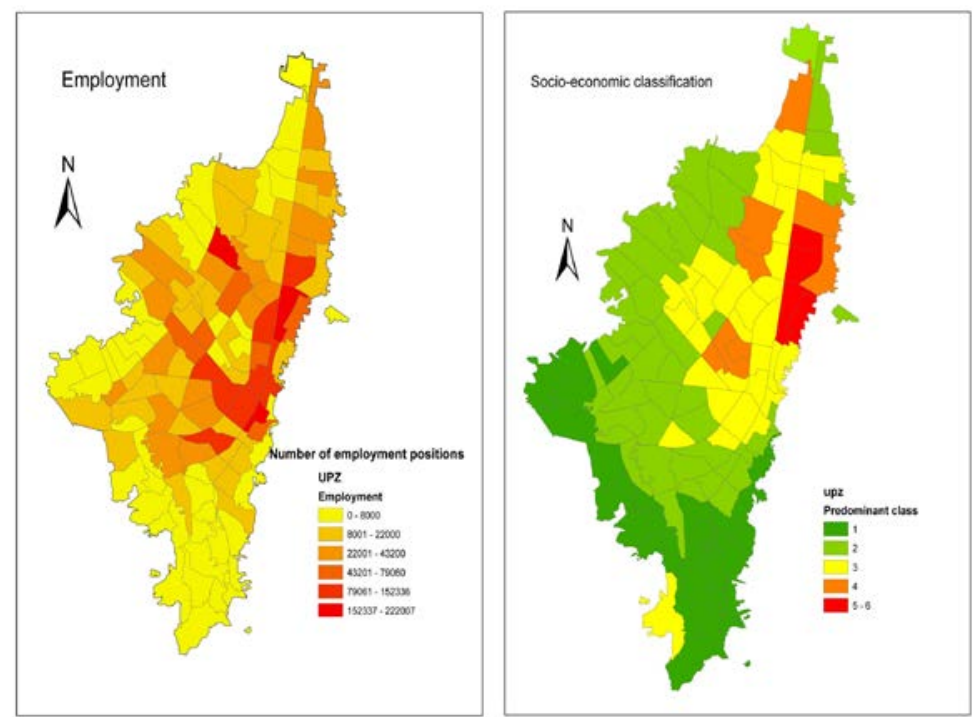

Figure 1 - Bogotá DC: Spatial distribution of employment opportunities and socio-economic groups of the population

Source: Bocarejo \& Oviedo, 2012

As a result of the economic and social structure of the city, Bogotá's transport infrastructure 
is especially strong in the central areas. Most of the primary road network is then linked to the main axis of activity and the mass transit services connect residential areas with the centres of opportunities. One of the biggest changes in the structure of Bogotá's transport network has been the implementation of Transmilenio a Bus Rapid Transit (BRT) system, whose contribution to the improvement of transport conditions in the capital has been remarkable. On average, Transmilenio improved travel speeds from $13 \mathrm{~km} / \mathrm{h}$ during the 1990's to $26 \mathrm{~km} / \mathrm{h}$ during its first phase in 1999 (Gakenheimer, 2000). Being one the first main success stories among Bus Rapid Transit systems in the developing world after Curitiba, Transmilenio has become a worldwide example in transport practice, not only increasing the connectivity of the public transport network, but also having positive impacts in terms of air quality and urban development.

However, Bogotá is still marked by important inequalities in terms of access to opportunities, as well as difficulties to use the transit system by the most vulnerable segments of the population. On average, Bogotá's citizens make 1.5 trips per day taking about an hour to commute. Low-income households spend more than $20 \%$ of their income accessing productive activities in sum to elevated walking times for accessing public transport particularly in the peripheries (Oviedo \& Bocarejo, 2012).

These conditions are likely to be replicated in areas with low coverage of public transport or where there is a discontinuity in transit services or infrastructure. However, this situation is likely to be aggravated by increasing distances and stronger conditions of poverty. The municipality of Soacha, located towards the south of Bogotá, is in this context an appealing object of analysis.

The spatial and functional conurbation Bogota-Soacha is the most intense in the region becoming the preferred destination for low-income migrants in recent years in spite of conditions of low governance and limited investment capacity. Soacha has the largest municipal population in the state of Cundinamarca (Figure 2). According to DANE data, in 2000 Soacha had 344,761 inhabitants and grew at an annual rate of over $6 \%$, well above the national average of $1.2 \%$. By 2010 , the municipality was home to 455,992 inhabitants, one of the most populated urban areas in Colombia (DANE, 2005).

This increase in Soacha's attraction for low income housing added to other migratory phenomena generating a high population growth in the municipality has influenced greatly the dynamics of conurbation with Bogotá. According to the 2003 census of Soacha, nonmigrants represented $14.6 \%$ of the population; while migrants were $81.6 \%$ (CCB, 2005). The continuous increase of urban population in the vicinity of Bogotá has generated some pressure for better connectivity for the workforce that travel between the two cities, which have been mainly challenged by political and administrative limitations.

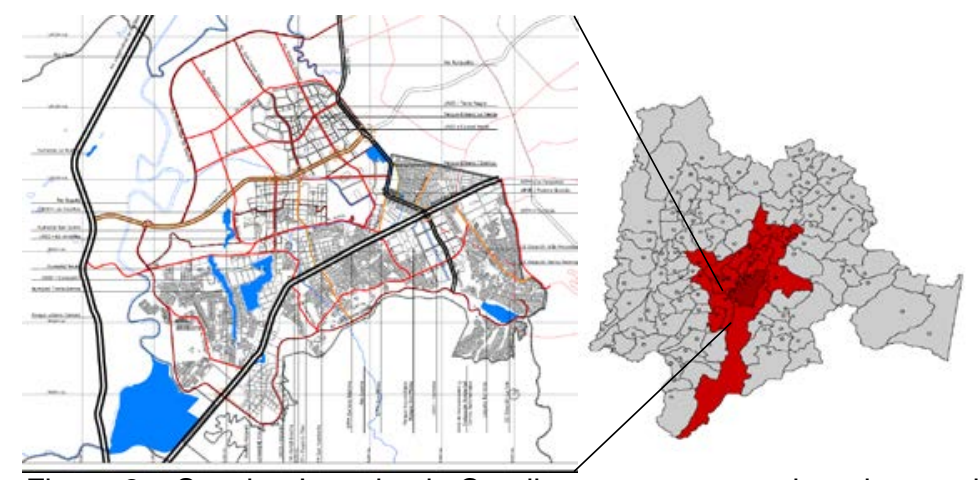

Figure 2 - Soacha: Location in Cundinamarca state and road network

Source: POT (2011) 
The basic structure of the road network in Soacha is derived from one of the most important roads in the national network that connects the central region with the southwest and east of the country (Figure 2). This corridor plays a central role in the national logistic network by linking hubs of industrial production with the high-capacity airport of Bogotá (POT, 2011). The existence of this strong transportation link has allowed the development of transport facilities, access to water supply and location of different activities, particularly in the mining industry.

Because it also works as a link between Bogotá and Soacha, the highway has been a determinant factor in the development of the conurbation between the two cities. As it gives Soacha strategic features in terms of connectivity to Bogotá in sum to its peripheral nature, the highway became one of the main reasons for the significant development of low cost housing by both formal and informal developers as well as occasional organized and spontaneous squatting on private and public plots of land. Rapid growth combines with conditions of poor governance and severe institutional weaknesses in the municipal government, making provision of utility and communication networks very difficult in many settlements (CCB, 2005; Acevedo et al., 2012).

\section{Informal settlements in Soacha: Social and Spatial Periphery}

The latest Municipal Development Plan states that Soacha has one of the highest migration rates of ethnic minorities in the country, mostly due to internal forced displacement arising from the low-intensity internal conflict that Colombia has undergone in the past four decades. Of these minority groups, the majority locates in urban areas, in poor and overcrowded conditions, especially in the case of indigenous groups (PMD 2008-2011). Most migrant population is of low income, have scarce or zero education, and do unqualified work. Migrants travel to Bogotá in search of a better quality of life and access to education and employment, but settle in Soacha mainly because of lower land prices. Additionally, certain groups of migrants from Bogotá move to Soacha attracted by the possibility of acquiring new low-cost housing or building lots at bargain prices without having to renounce to opportunities in the main city (UNHCR, 2005).

These conditions push migrants and people searching for acquiring local housing at bargain prices to settle in areas where the prices are lower within the municipality. However, the spatial nature of this periphery is reinforced by a social and economic nature resulting from the internal dynamics that take place in the settlement and the conditions of vulnerability related to limited access to adequate living conditions.

Most displaced families locate in areas that either unsuitable for housing or that present barriers for physical access. According to data from UNHCR, three of the six Comunas in which Soacha is divided have a low coverage of utility networks and are marked by high geological and seismological risks. These same areas concentrate most of the displaced population (UNHCR, 2005).

The rest of the paper focuses in an area in Comuna 4 of Soacha called Altos de Cazucá, one of the settlements that house a large number of low-income in-migrants and has one of the fastest dynamics of development and consolidation of informal settlements in the municipality. This neighbourhood is not only framed in the city-periphery dynamics between Bogotá and Soacha but it is located on the administrative boundary between the two cities (Figure 3), being peripheral to both structures of connectivity. 


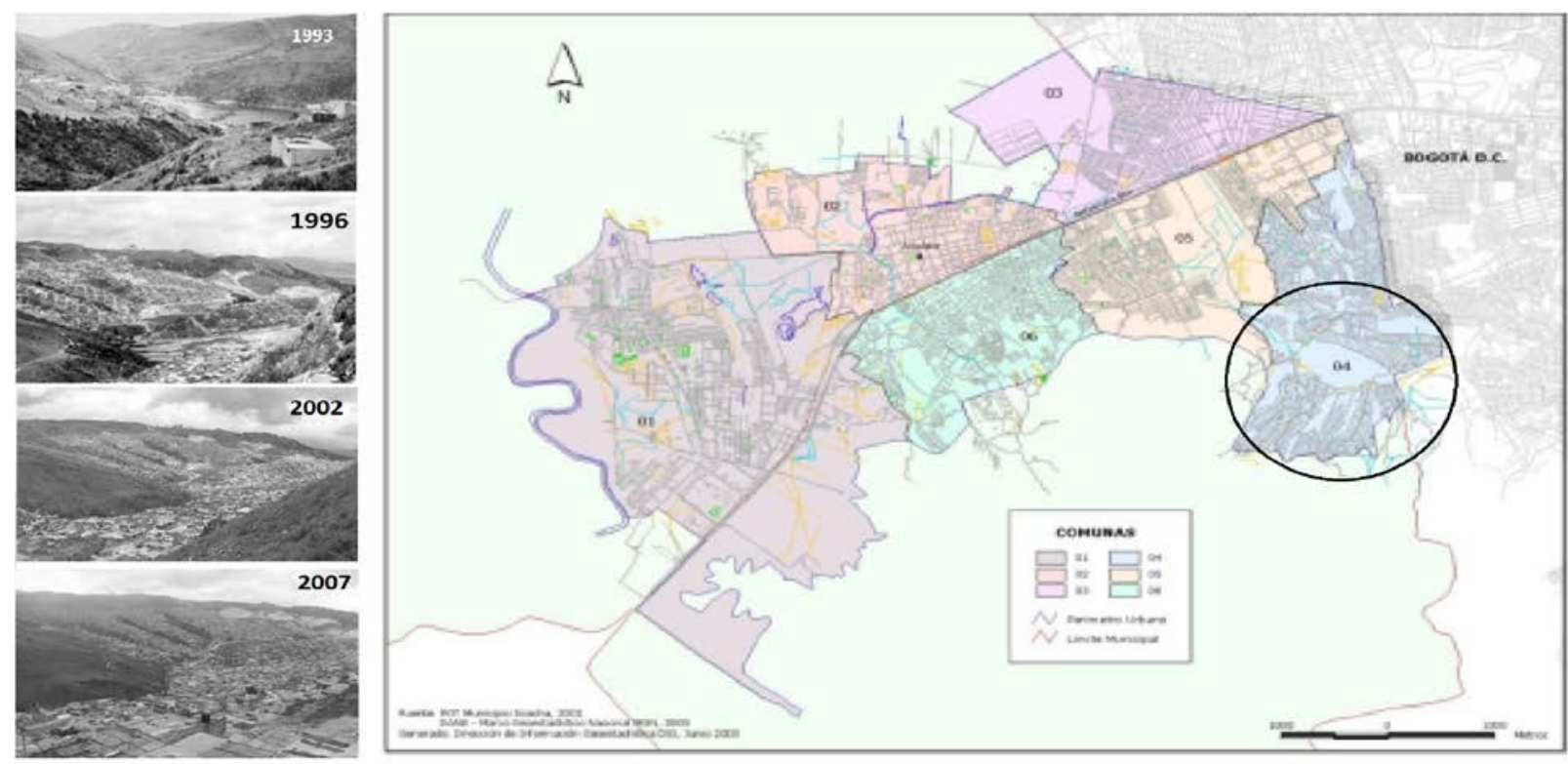

Figure 3 - Location of the case study and timeline of informal developments in Altos de Cazucá

Source: POT (2000), Torres (2008) and Acevedo et al., (2012)

One of the most striking features of Altos de Cazucá is its very rapid development. As seen from the photographs in Figure 3 and the timeline in Figure 4, the beginning of the urbanization of this neighbourhood can be traced back 20 over years, being scarcely occupied by 1993. However, only three years after, as a result of the occupation and development by an informal housing promoter, or pirate developer, the neighbourhood started spreading having reached important levels of consolidation only six years later. Currently, the study area has reached the limit with Bogotá and is separated only by an imaginary administrative boundary and contained by a mountainous area in the south.

Utility networks in Soacha are insufficient for the size and growth of its population. This is primarily explained by public underinvestment and rapid and chaotic urban growth, which poses difficulties for adequate institutional response in terms of health, education, housing and security. By $2005,96.7 \%$ of households were supplied with electricity, $82.8 \%$ with water supply $83.6 \%$ with sewerage (DANE, 2005). In the case study neighbourhood, however, levels of access to utility networks are much lower than the average for municipality. In fact, in a population of 69,325 inhabitants in $2005,74.7 \%$ did not have access to water supply, $66.2 \%$ were not covered by sewerage and $63.6 \%$ were not served with natural gas (Acevedo et al., 2012).

These conditions add to a long list of limited availability of resources and assets required to overcoming poverty. Not only people in the case study have very constrained access to adequate living conditions and infrastructure, they also have limited choice for accessing income-earning opportunities as they consist largely of unskilled labour force and often work in the informal sector. The census shows that, at 4.73, Altos de Cazucá has Soacha's lowest average in terms of years of formal education (DANE, 2005).

Moreover, the municipality also high levels of unemployment, with even more critical levels in Altos de Cazucá. The Municipal Development Plan (PMD) estimates unemployment in the municipality at around $15.6 \%$ affecting especially groups aged 15 to 24 (CCB, 2005). The municipality, particularly in the poorest areas, presents high incidence of child labour generating conditions for the intergenerational transmission of poverty. About $55 \%$ of Soacha's economically active population works in Bogotá despite the high presence of manufacturing industry and a recent reactivation of the local economy. In the case study area, the patterns of travel for accessing income-earning opportunities usually involve long 
periods of travel towards Bogotá which are not only subject to long walking times and high financial outlays for individuals and their households, but are also constrained by local dynamics of crime and violence that limit the areas and times where it is possible to travel on foot (POT, 2011; Acevedo et al., 2012).

Previous works conducted in the area suggest that the main social and economic problems of Altos de Cazucá are mainly related to limited purchasing power, long working hours, single-parent households, and difficult access to employment and education (Acevedo et al., 2012). According to empirical evidence, most workers of the comuna have precarious job conditions, low salaries, variable income, and informal job contracts. In this case, besides some spatial barriers for accessing income, the main constrains when obtaining a job were related to lack of qualifications and social stigmas related to the high incidence of crime and insecurity in the neighbourhoods, reducing considerably the opportunities for interaction of the inhabitants of the case study (Acevedo et al., 2012).

The characteristics of Altos de Cazucá suggest segregation beyond the merely spatial interpretation. The limited access of its inhabitants to an adequately built environment evidences low social investment and lack of consideration in the official development plans. In spite of the informal nature of most of the settlements, the relational position with respect to the social and economic structure of Bogotá and Soacha, both seen as independent entities or as part of the same urban space, evidences a functional relationship that needs to be well-thought-out from both sides of the border. Moreover, these conditions reinforce the insufficient availability of mechanisms to the households of Cazucá to access opportunities of the region, being also subject to social exclusion as a result of economic, spatial and social reasons linked to the place where they reside.

\section{Fragmented connectivity}

The evolution of informal settlements in Altos de Cazucá and the high consolidation rates achieved are in part a result of the existence of roads leading to older developments closer to the main highway. Moreover, in the processes of urbanization of this area, developers took advantage of the small road networks used for quarries in some of the mountains adjacent to the neighbourhood. However, it can be argued that the pre-existence of these precarious networks led in part to the fragmented connectivity of the settlements with the rest of the fabric, and the current sub-investment in road infrastructure.

The main road connection to the neighbourhood is the somewhat grandly termed Avenida Terreros, which was there long before the urbanization processes in Altos de Cazucá and that served as connection to the main highway for heavy vehicles and machinery that operated in the quarry. This corridor progressively became the central axis for the operation of public transport routes that started serving the increasing demand that was consolidating after 2000. During the following years, as a result of the dynamics of urbanization and the further consolidation of developments closer to the main corridor connecting Soacha with Bogotá and the own dynamics of development of altos de Cazucá, a basic road network was created that has not been substantially upgraded in the past 10 years. The lack of public investment in the area has led to an incomplete network of low capacity and poor levels of service. These roads not only present insufficient conditions for the adequate circulation of motorized transport but also pose a constraint for pedestrian displacement as there is insufficient space for sidewalks or kerbs.

According to the Land Use Plan (POT, 2000) in the municipality in general, 49\% of roads in were unpaved, $34 \%$ had fair pavement quality and only $17 \%$ were considered in good conditions. As shown in Figure 4, the study area has one of the most underdeveloped road networks of the whole municipality evidencing the lowest capacity, high levels of surface and structural damage and that in most of the cases are unpaved. Most of the local roads feature poor design and are too narrow for adequate two-way traffic (CCB, 2005). 

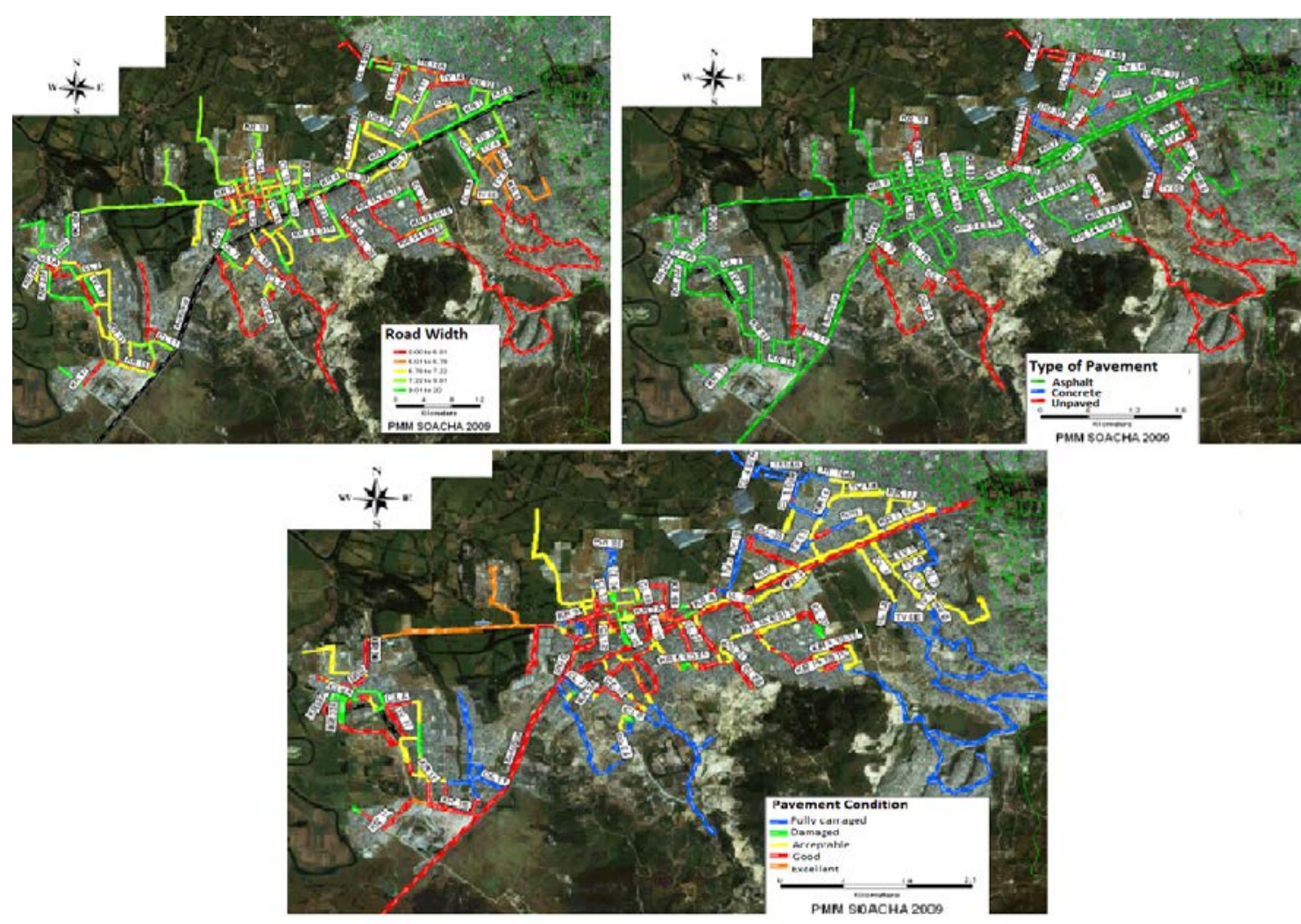

Figure 4 - Location of the case study area and timeline of informal developments in Altos de Cazucá

Source: Master Plan of Transport for Soacha (2009)

Figure 4 shows the results of a diagnosis contained in the Master plan of Transport for the municipality, developed between 2008 and 2009 which implies a level of awareness of the problematic in infrastructure and transport planning at the municipality. However, it is also clear by the conditions of the road network in Altos de Cazucá in relation to other Soacha comunas, that the relative attention paid to this area has been considerably lower, if not inexistent with respect to more central or strategic areas of Soacha where at least, according to the criteria used for road assessment, the condition of surfacing is acceptable while in Comuna 4 they are not even surfaced.

The limited provision of material infrastructures of connectivity in the case study area has clear implications in terms of the availability of transport services there. Considering the few suitable corridors for transit operation in the area, it is not surprising that the number and type of public transport available is as limited. As shown in Figure 5, although the coverage of public transport is limited in the municipality, the study area (number 2 in the figure), has the lowest provision of transport routes, which, also limited by the available infrastructure, does not reach most of the settlement (Transmilenio, 2009). 


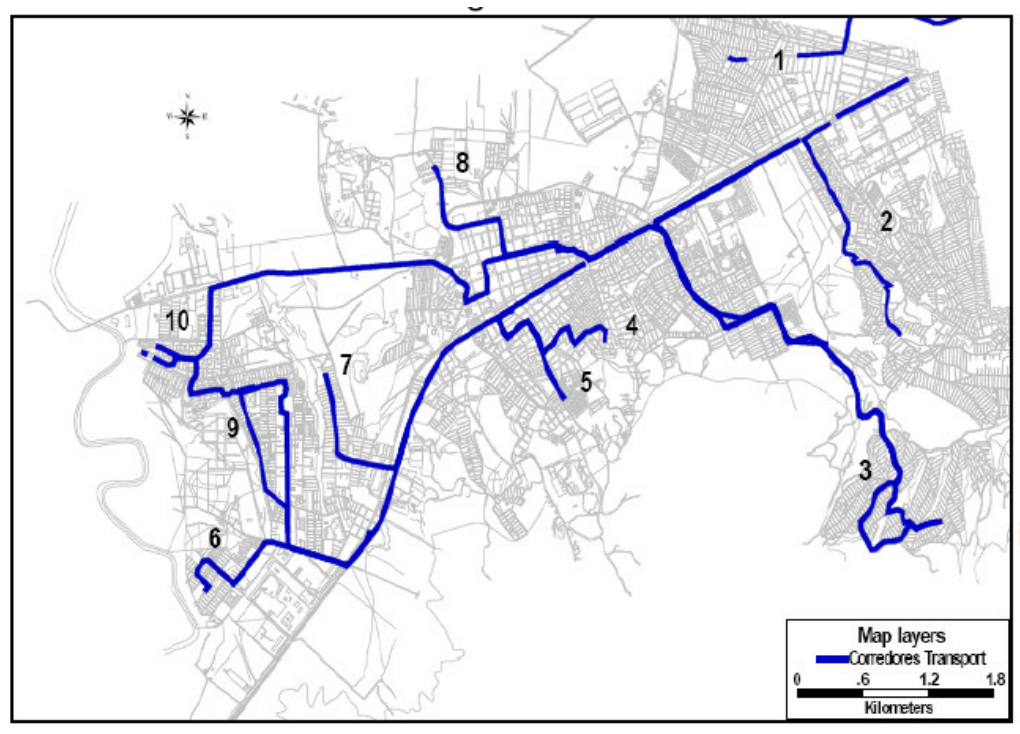

\begin{tabular}{|c|l|}
\hline \multicolumn{2}{|c|}{ Main Public Transport Routes } \\
\hline 1 & León XIII \\
\hline 2 & Cazucá \\
\hline 3 & Ciudadela Sucre \\
\hline 4 & San Humberto \\
\hline 5 & San Carlos \\
\hline 6 & San Nicolàs \\
\hline 7 & Ducales \\
\hline 8 & Danubio \\
\hline 9 & Compartir \\
\hline 10 & Ciudad Latina \\
\hline
\end{tabular}

Figure 5 - Coverage of transit services

Source: Transmilenio (2009)

The general evolution of transport networks in parallel to the development of Altos de Cazucá has been only in scale as demand increases. Although there is now a higher number of transit routes with higher frequencies, its scheme has not changed considerably and serves mostly the local level. In fact, $98 \%$ of the routes in Altos de Cazucá operate only at the local level, covering practically only trips from the inner settlements to the main highway, where the routes that provide services towards Bogotá or even downtown Soacha circulate (Transmilenio, 2009).

In general these features limit considerably the accessibility from the area of analysis. First, the lack of good-quality transport infrastructure and transit services makes access times particularly high. The low number of corridors for public transport operation, unequal frequencies and limited services, generate considerable barriers for interaction and increases considerably transport expenditure as a result of forced transfers. Assuming a legal minimum salary of approximately 240 USD, in the late 2000 s it was estimated that the daily transport needs of one individual in a household represented an average of $16 \%$ of household income (Metro de Medellín, 2008).

In addition to the limited number of connections available, their quality is considerably low, evidencing severe flaws in the service. The public transport fleet in Soacha is old, with $76 \%$ of the fleet being older than 11 years. Moreover, schemes of operation are inefficient, particularly given the excessive number of low-capacity vehicles. Frequencies are unequally distributed, maintaining service over-supply even in non-peak periods.

Acevedo et al. (2012) established from empirical evidence and interviews that the main transport problems in Altos de Cazucá are mainly related to the inadequate provision of transport infrastructure and services, low accessibility as well as economic and personal barriers for accessing public transport network. According to the same source, this has severe implications in terms of prescribing mobility patterns and limiting the levels of interaction of the people in Cazucá with the opportunities in Soacha, Bogotá and the rest of the Capital Region.

In fact, there is a generalized low travel production in the municipality of Soacha, at 0.55 trips/day/person in 2005 and 0.61 in 2009, which even for low-income standards in Bogotá is very low (the average of the lowest socioeconomic strata in Bogotá is 1.1). However, this production unevenly distributed in space, with the case study area having one of the lowest rates of trip generation in the whole municipality, as shown in Figure 6. 

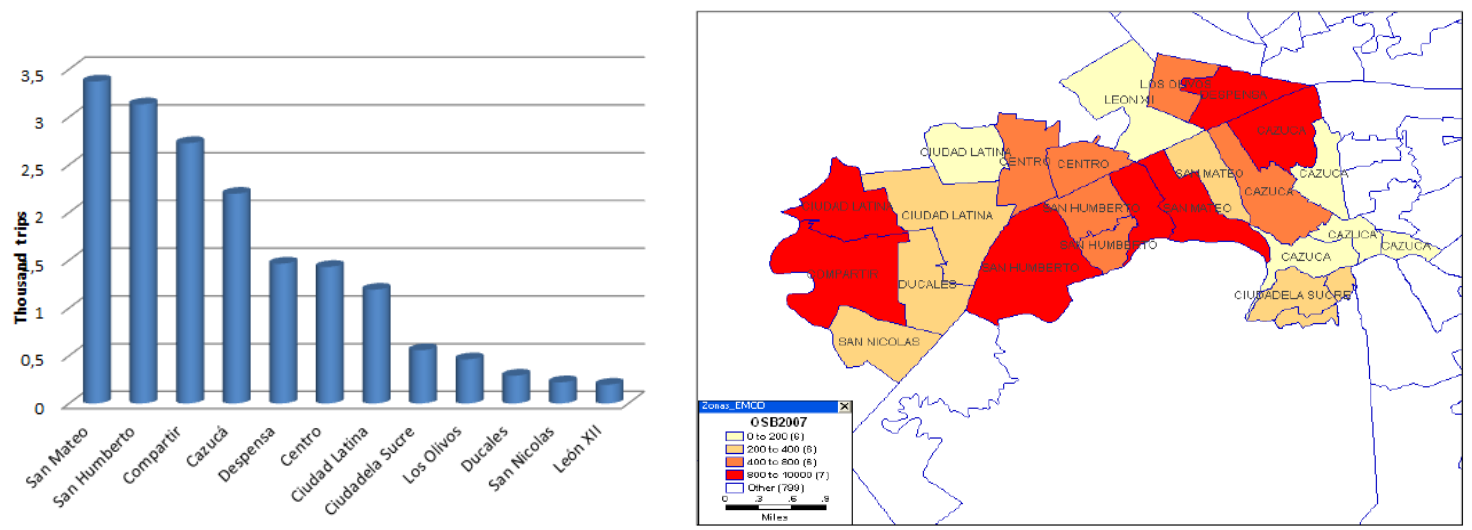

Figure 6 - Soacha comunas: Trip generation to Bogotá

Source: Transmilenio (2009)

Moreover, it is clear that due to the specific characteristics of travel demand in the case study Soacha does not provide opportunities that can be easily accessed by the population. This is reflected in the $85 \%$ of transport demand in the peak hour traveling to Bogotá, involving distances of between 17 and $24 \mathrm{~km}$. From the 17,136 trips directed to Bogotá from Soacha during peak hours, $15.06 \%$ corresponded to Altos de Cazucá, evidencing the strategic importance in terms of demand of this area.

In addition, transport demand from the study area is captive to public transport services. $85.1 \%$ of the trips generated are made via public transport, with an average travel time of 79.3 minutes. $8.6 \%$ of internal trips (i.e. within Soacha) are non-motorized, with an average travel time of 40.2 minutes. Moreover, the use of transport services only at a local level involves high levels of expenditure in travel for most of the population in the study area. On average, only 6\% of Soacha residents spend up to 1 USD per trip, 55\% between 1 and 2.5 USD, and 39\% more than 2.5 USD per trip. In an area where most household incomes are close to the minimum salary these levels of expenditure hinder mobility for household members and reinforce social inequalities and exclusion across the conurbation.

\section{Recent changes in Infrastructure Policy}

An extension of Transmilenio BRT from Bogotá to Soacha has been openly discussed since the beginning of the 2000s with the aim of supplying an increasing demand from a work force that makes a non-trivial contribution to the economy of the capital city. In 2002 the National Council of Social Policy (CONPES) officially identified the need to develop an integrated transit system between Bogotá and Soacha. The results of this initiative were an initial study of traffic demand between the two municipalities and a first proposal for the project. However, due to political and economic difficulties the project stalled and was suspended until a new approach for both its financing and operation could be developed.

In 2005, policy-makers decided to increase the capacity of the southern highway that traverses Soacha as part of a project for improving the Bogotá-Girardot highway. The project included a major road upgrading including the extension of its transversal profile. A concession contract was awarded with national government funds. However, due to the requirements of intervention in a section of the road of approximately $6 \mathrm{~km}$ for the extension of Transmilenio within Soacha it was decided to include transit infrastructure as part of the general concession.

As a result of this decision, which was ultimately taken at the national level, a new contract was signed for the technical restructuring of the BRT system in Soacha that responds to the 
new specificities of the project. In this case, Transmilenio S.A., undertook a study to measure demand and the development of alternatives for an operational scheme to integrate with the existing mass transit network within Bogotá. This project includes the restructuring of routes and local improvement in the coverage of public transport in the municipality, implying fleet size reduction and optimization of vehicle distribution.

The final design of the project currently under development is shown in Figure 7. The Bus Stops of the BRT Service are shown in Red while feeder and complementary routes are shown in green and blue.

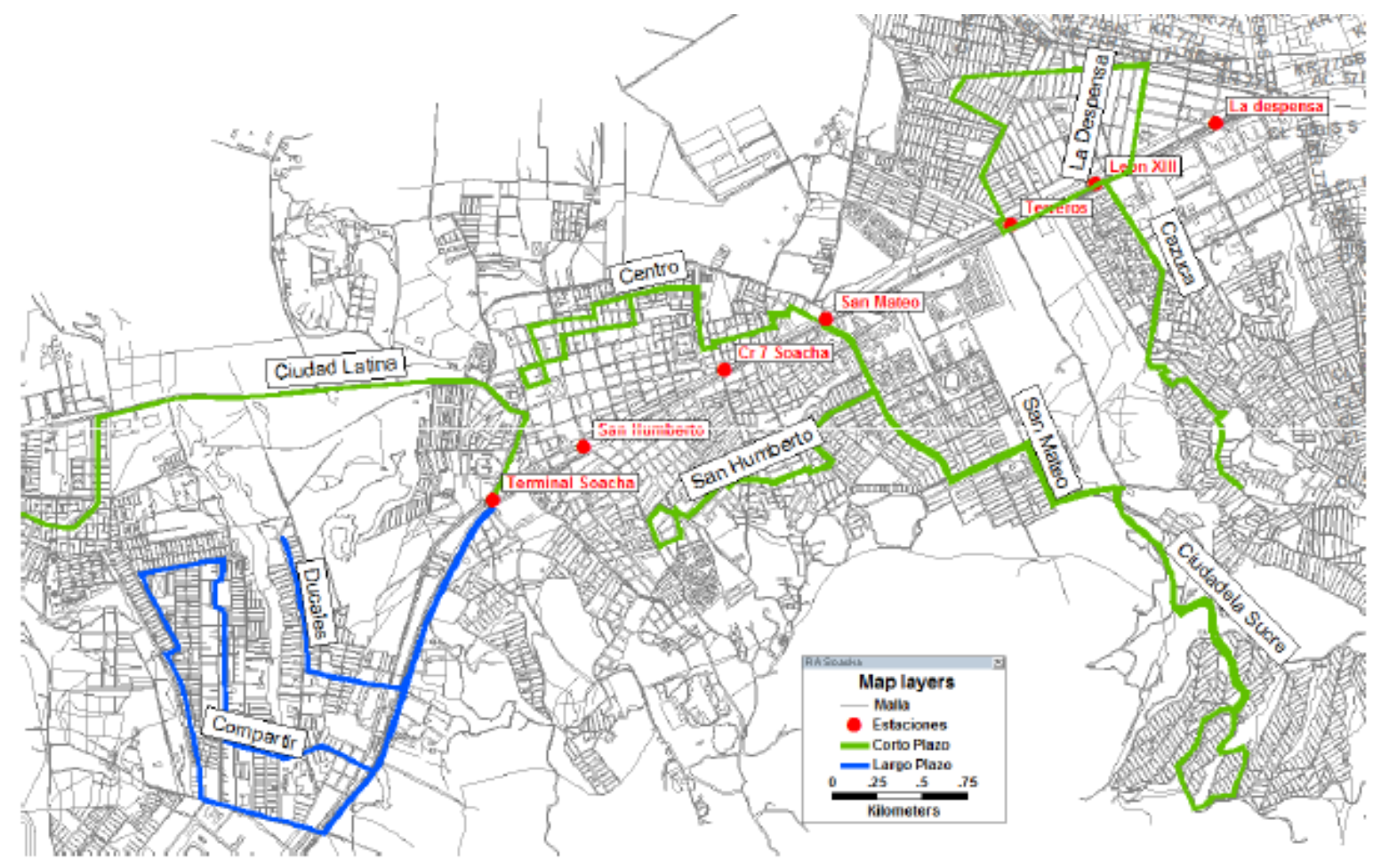

Figure 7 - Operational Scheme of Transmilenio in Soacha

Source: Transmilenio (2009)

Although its operation goes beyond the timeline set for the analysis of this research, this project represents a change in the tendencies of transport service provision, and to some extent infrastructure, in the municipality. However, the decision making processes involved in the definition of this new system in the municipality is a clear example of the fragmentation in spatial and infrastructure planning in centre-periphery systems like the Bogotá-Soacha region. In fact, the decision to develop this infrastructure emanates from a national government decision to develop road network of national importance such as this one that, by chance, goes through Soacha. Although the schemes of operation of the extended Transmilenio depend on demand conditions in Soacha, the main determinants for the development and implementation of the project lie outside the municipality's jurisdiction.

Although in theory the municipality was one of several project stakeholders, most of the decisions regarding the project were in fact made by Transmilenio, which is an institution based in neighbouring Bogotá. In this case, as the less powerful actor at the table, Soacha's interests were subservient to Bogotá's. This is reflected in the technical design for the case study. As can be seen in Figure 7, the feeder system for the BRT in the area of Altos de Cazucá is still limited by the same corridors that the current public transport uses to operate. 
The additional investment in road infrastructure to increase coverage was then discarded, even though the project involves a funding contribution from the municipality. Moreover, the travel patterns of Soacha residents reveal that some of the main travel destinations in Bogotá, especially for residents in Altos de Cazucá are not covered by Transmilenio. In the absence of an integrated single-fare system, for users the transfers involved compound the already high Transmilenio fare compared to current bus services.

While the benefits of the system are by no means undermined by this analysis, it is clear that they are rather limited for residents of the case study area. In particular, it fails to solve the issues of connectivity in the neighbourhoods and increases the cost of the service. Moreover, according to Bocarejo \& Alvarez (2012), as a result of the conditions of low income and illiteracy in the population, a more organized system like Transmilenio has several perceived access limitations like costs and the difficulty of getting around the system. This limits the travel choice of the population to conventional public transport (buses and shared taxis) and walking, with the resulting problems of long walking distances, long travel times, and low trip generation in households.

\section{Splintering Urbanism?}

In the light of the theoretical discussion introduced in section two, the case study would seem to confirm that there is a level of applicability of Graham and Marvin's thesis to the analysis of provision of transport infrastructure and services in peripheral areas in at least one city of the Global South. The most useful elements in the analysis of the case study are then related to the interpretation of networks as a socio-techical construct that is shaped by the power and influence of different groups in society. In this case, due to the lack of power and influence of some groups, they are bypassed in the process of development of connectivity networks.

In this case power relations can be seen at two scales. The first one is the relationship Bogotá-Soacha that limits the generation of strong networks of connectivity between the two administrative figures in spite of a level of functional integration that is not able to operate more effectively due to a lack of connections. The presence of a nationally relevant road connecting the two cities not only has defined to a great extent the way in which Soacha has developed but also the areas where most of the resources in the municipality that are available for infrastructure and transport development are used. The second scale is at a more local level. The position of Altos de Cazucá in both spatial, social and political terms make of this neighbourhood the perfect case of a bypassed node in the processes of provision of transport networks. The lack of influence and political representation of the high number of internally displaced people residing in this area can be easily linked with the availability of transport infrastructure and services in the neighbourhood.

The second element that can be drawn from splintering urbanism is the fragmentation of connectivity networks in these bypassed nodes within social structures. In contrast to the premium spaces that have been thoroughly analysed under this approach, the case study presented here, when seen merely in terms of transportation, offers an important level of disconnection that leads to conditions of exclusion or at least, to a very limited capacity of interaction. The evidence from the case study shows the consequences of a limited provision of networks of physical connectivity. The lack of public-sector investment in the study period is reflected not only in the physical deterioration of the infrastructure network in Altos de Cazucá but also in the poor capacity for vehicle circulation. Drawing from the role of material infrastructures for connectivity in the normal development of society and reduction of inequalities, it is clear that by limiting the interventions in these vulnerable areas, some barriers are imposed to the flows of demand to the social system of Soacha and the cityregion that it forms with Bogotá. 
The Splintering Urbanism thesis appears to be corroborated in the specific case outlined here. It is also useful in helping structure an analysis of the processes involved in transport networks to less powerful groups in society, its causes, but most importantly its consequences. While it does not constitute a formal research approach to a specific case study or even the analysis of a given sector, Graham and Marvin's argumentation provides useful hints about the main elements that might play a role in the generation of spatial inequalities. Moreover, it can be argued that one of the main contributions in the analysis of transport networks is the development of a more comprehensive assessment of these dynamics beyond either the merely technical or political approach. By incorporating a spatial dimension within a sectoral policy analysis the framework facilitates the identification of inequalities and flaws in planning and in the prioritisation of public investments, providing a more politically and sociologically informed critique of what is often seen as a merely technical issue such as the design of the provision of transport services and infrastructure.

\section{REFERENCES}

Acevedo, J., Velásquez, J. M. and Bocarejo, J. P., 2012, "La promesa presidencial de un cable aéreo: Limitaciones institucionales y realidades políticas", in Dávila, J. (editor), Urban Mobility and Poverty: Lessons from Medellín and Soacha, Colombia, Development Planning Unit, UCL, and Universidad Nacional de Colombia, London.

Alvarez. M. J. and Bocarejo, D., 2012, "Contexto socio-económico de la Comuna 4 de Soacha: Vulnerabilidad, encierro y estigma", in Dávila, J. (editor), Urban Mobility and Poverty: Lessons from Medellín and Soacha, Colombia, Development Planning Unit, UCL, and Universidad Nacional de Colombia, London.

Bassols, M. (nd), "La marginalidad urbana: Una teoría olvidada".

Bauman, Z., 2000, Liquid Modernity (Cambridge Policy press)

Bocarejo S., J. P., Oviedo H., D., Transport accessibility and social inequities: a tool for identification of mobility needs and evaluation of transport investments, Journal of Transport Geography, Volume 24, September 2012, pp 142-154

Brand, P. and Dávila, J. 2011, "Mobility innovation at the urban margins: Medellín's Metrocables", City, Vol. 15, No. 6, pp. 647-661.

Burchardt, T., (1999) cited in F. C. Hodgson and J. Turner (2003) Participation not consumption: The need for new participatory practices to address transport and social exclusion. Transport Policy 10, p. 272.

Cámara de Comercio de Bogotá -CCB-, 2005, Plan económico para la competitividad de Soacha, Bogotá, Report.

Cámara de Comercio de Bogotá -CCB-, 2012, Informalidad Empresarial y Laboral en Colombia y Bogotá. Bogotá, Report.

Castells, M., 2000b, The Rise of the Network Society, Second Edition. U.S.: Blackwell Publishing

Church, A., Frost, M. and Sullivan, K. (2000) Transport and social exclusion in London, Transport Policy 7: 195-205

Coutard, O., 2002. Premium network spaces: A comment. International Journal of Urban and Regional Research 26 (1), 166-174. 
Dávila, J. (editor), 2012, Urban Mobility and Poverty: Lessons from Medellín and Soacha, Colombia, Development Planning Unit, UCL, and Universidad Nacional de Colombia, London.

Departamento Administrativo Nacional de Estadística -DANE-, 2005. National Census. Report.

Departamento Administrativo Nacional de Estadística -DANE-, 2005. Proyecciones Nacionales y Municipales de Población. Database.

Departamento Nacional de Planeación -DNP-, 2005. Visión Colombia 2019. II centenario. Construir ciudades amables.

DPU, 2006, "Housing and Land for the Urban Poor. Case Studies of Bogotá-Soacha and Medellín", unpublished report for World Bank-Cities Alliance and the Colombian Government.

Fernández-Maldonado, A. M., 2008, Expanding networks for the urban poor: Water and telecommunications services in Lima, Peru, Geoforum 39, pp1884-1896

Gakenheimer, R. (1999). Urban mobility in the developing world. Transportation Research Part A 33, 671-689.

Graham, S., Marvin, S., 2001, Splintering Urbanism: Networked Infrastructures, Technological Mobilities and the Urban Condition, Routledge, London.

Grieco, M., 2006, Accessibility, Mobility and Connectivity: The Changing Frontiers of Everyday Routine, European Spatial Research and Policy (Special Issue) 78 (6), 1360-80.

Kenyon, S., Lyons, G. \& Rafferty, J., (2002) 'Transport and Social Exclusion: Investigating the Possibility of promoting Inclusion through Virtual Mobility'. Journal of Transport Geography, Vol. 10, pp 207-209.

Manderscheid, K., 2009, Unequal Mobilities in T. Ohnmacht, H. Maksim and M.M. Bergman (eds), Mobilities and Inequality, Ashgate, Aldershot, UK. pp 27-50.

Manderscheid, K. and M. M. Bergman, 2008, Spatial Patterns and Social Inequalitiy in Switzerland - Modern or Postmodern? In: G. Pflieger, L. Pattaroni, C. Jemelin and V. Kaufmann (eds.). The Social Fabric of the Networked City, Routledge: 41-65.

Metro de Medellín, 2008, Estudio social, proyecto de prefactiblidad del cable aéreo en el municipio de Soacha, Medellín, Report.

Ohnmacht, T., Maksim, H., and Bergman, M.M., (eds), 2009, Mobilities and Inequality, Ashgate, Aldershot, UK.

Oviedo, D., Bocarejo, J.P., Desarrollo de una metodología de estimación de accesibilidad como herramienta de evaluación de políticas de transporte en países en desarrollo: Estudio de caso de la ciudad de Bogotá, Revista de Ingeniería Universidad de los Andes, Volume 35 , July 2011, pp 27- 33.

Plan Maestro de Movilidad de Soacha -PMM-, 2009. Soacha, Official Report.

Plan de Ordenamiento Territorial de Soacha -POT-, 2000. Soacha, Official Document.

Revisión del Plan de Ordenamiento Territorial de Soacha -POT-, 2011. Soacha, Official Document

Quijano, A., 1977, Imperialismo y Marginalidad en América Latina, Mosca Azul, Lima.

Transmilenio S.A., 2009, Actualización Del Estudio "Asistencia Técnica Para La Reorganización De Transporte Público Colectivo Y La Estructuración Técnica, Financiera Y Legal Del Esquema De Alimentación Para La Extensión De Transmilenio Al Municipio De 
Soacha". Y "Estudio De Demanda Potencial Del Proyecto Aerosuspendido De CazucaCiudadela Sucre.". Report.

Torres, C., (2008). Ciudad hábitat y vivienda informal en la Colombia de los años 90. Grupo de investigación: Procesos urbanos informales. Bogotá: Universidad Nacional de Colombia

Witter, R., 2010, Public urban transport, travel behaviour and social exclusion - The case of Santiago de Chile. XII World Conference on Transportation Research, Lisbon, July 2010.

Zérah, M., 2008, Splintering urbanism in Mumbai: Contrasting trends in a multilayered society, Geoforum 39,1922-1932. 